\title{
Exposure of Arenicola marina to extreme temperatures: adaptive flexibility of a boreal and a subpolar population
}

\author{
A. Sommer, H. O. Pörtner* \\ Alfred-Wegener-Institut für Polar- und Meeresforschung, Biologie I/ Ökophysiologie, Columbusstrasse, \\ D-27568 Bremerhaven, Germany
}

\begin{abstract}
Adaptive flexibility under temperature stress was studied in a boreal and a subpolar population of Arenicola marina (L.) from the North and White Seas. Temperature stress leads to the onset of anaerobic metabolism and the ability to acclimate is interpreted to be associated with a reversal of this initial transition to anaerobiosis, restoring total aerobic conditions. Thus, end products of anaerobic metabolism as well as adenylate and ammonium concentrations were measured as indicators of temperature stress. The results reveal that the populations differ in their ability to acclimate to temperatures $4^{\circ} \mathrm{C}$ above their respective high critical temperature. Lugworms from the North Sea survived for only slightly longer than $1 \mathrm{~d}$, while concentrations of alanopine and strombine were significantly elevated. However, adenylate and ammonium levels remained close to control values. In contrast, White Sea specimens showed drastic changes in the concentrations of anaerobic end products and ammonium, and ATP pools were depleted to levels below detection limits during the first $24 \mathrm{~h}$ at high temperatures. A higher metabolic proton production in White Sea worms, together with a lower intracellular non-bicarbonate buffer capacity led to a drastic drop in intracellular $\mathrm{pH}$, whereas acidosis was only moderate in North Sea worms. Unexpectedly, the subpolar worms not only survived heat exposure, but even exhibited an adaptive reversal of anaerobic metabolic changes. Whereas heat exposure was compensated in White Sea worms only, the short term ability to survive cold stress $\left(-1.7^{\circ} \mathrm{C}\right)$ is $\mathrm{lim}$ ited in summer worms from both populations. Therefore, after an initial reversal of anaerobic metabolism, concentrations of volatile fatty acids and succinate increased again after $3 \mathrm{~d}$. Since White Sea worms can acclimatise to temperatures below $-2^{\circ} \mathrm{C}$ during winter, our data suggest, that in contrast to warm acclimation, cold acclimation requires a moderate and protracted decline in temperature.
\end{abstract}

KEY WORDS; Temperature adaption - Anaerobic metabolism - Arenicola marina $\cdot$ Heat stress · Cold stress · Adenylates · Polychaeta - Buffer capacity

\section{INTRODUCTION}

The intertidal zone is one of the harshest marine environments characterised by large fluctuations in abiotic factors. Therefore, intertidal animals must be able to tolerate changes in salinity, oxygen availability, carbon dioxide and sulphide concentrations during both diurnal and seasonal cycles, and they must also

- Addressee for correspondence.

E-mail: hpoertner@awi-bremerhaven.de cope with large temperature fluctuations. One of the model organisms studied extensively with respect to survival strategies in the intertidal is the lugworm Arenicola marina (L.). Research focussed on hypoxia adaptation (e.g. Toulmond 1975, Schöttler et al. 1983, Toulmond \& Tchernigovtzeff 1984) and some studies permitted insight into the survival under sulphidic conditions (Völkel \& Grieshaber 1992, Grieshaber et al. 1993). Temperature was an issue in early studies by Krüger (1964), Wells (1964), Seymour (1972) and Toulmond (1977) and has only recently regained interest (Schmidt et al. 1992. Hummel et al. 1997, Sommer et 
al. 1997). The most recent studies focussed on limiting temperature conditions and on metabolic adjustments during temperature adaptation.

Sommer et al. (1997) identified a high and a low critical temperature $\left(T_{c}\right)$ in the lugworm, both characterised by the onset of anaerobic metabolism when temperature rises or falls beyond those threshold values. It was hypothesized that at temperatures beyond each $T_{c}$ the energy demand of the lugworm cannot be met by aerobic means, so that additional anaerobic energy production is required. Between the $T_{c}$ values, intracellular $\mathrm{pH}$ in the body wall musculature of the lugworm changes in accordance with the $\alpha$-stat hypothesis (Reeves 1972 ), but beyond the $T_{c}$ 's the $\mathrm{pH}$ / temperature relationship is no longer linear (Sommer et al. 1997). The drop in $\mathrm{pH}_{i}$ at low temperatures coincided with the accumulation of anaerobic end products in the body wall tissue.

$\mathrm{T}_{\mathrm{c}}$ 's are variable during temperature acclimation and between populations of the same species. A shift to lower values was seen in winter adapted lugworms, and lower $T_{c}$ values were observed in lugworms from the White Sea compared to North Sea worms. The lower $\mathrm{T}_{\mathrm{c}}$ in White Sea specimens is associated with a higher aerobic capacity in these animals. An elevated density of mitochondria as well as a higher oxidative capacity of individual mitochondria lead to a higher rate of aerobic energy production at low temperatures and, consequently, to a shift of the low $I_{C}$ to a lower value (Sommer \& Pörtner unpubl.). The higher mitochondrial density causes an increase in standard metabolic rate at all temperatures (Sommer \& Pörtner unpubl.) and a concomitant shift of the high $\mathrm{T}_{c}$ to $\mathrm{a}$ lower value. This explains previous observations that latitudinal or seasonal temperature adaptation in Arenicola marina leads to a more or less parallel shift of both $\mathrm{T}_{\mathrm{c}}$ values (Sommer et al. 1997).

The studies mentioned so far might explain how the lugworm was able to conquer the subarctic waters of the White Sea some thousand years ago (Govberg 1973, Nesis 1983). They also lead to the question of how flexible the different populations may be with respect to present day and future temperature fluctuations, especially in the light of rising daily maximum. temperatures due to global warming (Easterling et al. 1997, Kaufmann \& Stern 1997, Gregory \& Oerlemans 1998, Kerr 1998). These changes should be accompanied by a rise in the frequency and magnitude of thermal fluctuations, which may well influence the distribution limits of a species. Our study was designed to investigate the potential to acclimate to acute heat stress (in comparison with cold stress) in a boreal and a subpolar population of the lugworm Arenicola marina during a short term period of a few days, a period not unusual for weather and temperature conditions in the
German Bight (North Sea) or the Kandalaksha Bay (White Sea). End products of anaerobic metabolism as well as $\mathrm{pH}_{\mathrm{j}}$ were measured as indicators of temperature stress, since the ability to acclimate is interpreted to be associated with the reversal of an initial transition to anaerobiosis (see above). Adenylate and ammonium concentrations were monitored for a more complete consideration of energy status and metabolism.

\section{MATERIALS AND METHODS}

Specimens. Specimens of Arenicola marina were collected in summer 1994 from intertidal flats slightly above the low water level of the North Sea near Dorum, Germany $\left(53^{\circ} 42^{\prime} \mathrm{N}, 8^{\circ} 35^{\prime} \mathrm{E}\right)$, ('North Sea worms') and of the White Sea near Kartesh, Russia $\left(66^{\circ} 20.8^{\prime} \mathrm{N}, 33^{\circ} 35.8^{\prime} \mathrm{E}\right)$, ('White Sea worms'). The body weight of the boreal lugworms was 5 to $8 \mathrm{~g}$, compared to 1 to $3 \mathrm{~g}$ for the subpolar worms. They were kept in the laboratory in aquaria filled with well aerated natural brackish sea water $(22 \%)$ and a $10 \mathrm{~cm}$ bottom layer of sediment. Temperatures were maintained at $12 \pm 0.5^{\circ} \mathrm{C}$ ('North Sea worms') or $6 \pm 0.5^{\circ} \mathrm{C}$ ('White Sea worms'). These temperatures corresponded to ambient water temperatures during collection time and are referred to as control temperatures.

In their natural environment boreal animals are rarely exposed to an ice cover on top of their burrows in January/February, whereas in summer the sediment can warm up to $25^{\circ} \mathrm{C}$ in those depths where the burrows are situated. The sea near Kartesh is normally ice covered for 6 to 7 mo each year, and the temperatures in the sediment can drop to $-5^{\circ} \mathrm{C}$ (Kolyakina 1980). During the short summer period the sediment temperature can reach $18^{\circ} \mathrm{C}$ (Sommer 1998).

Experimental procedure. Specimens were placed individually in 1-1 containers filled with sediment and sea water at control temperatures, where they were allowed to construct burrows. After 24 h of preincubation, the containers were transferred into aquaria containing sea water with different, pre-set temperatures $4^{\circ} \mathrm{C}$ above the respective high $\mathrm{T}_{c}$, i.e. to $21^{\circ} \mathrm{C}$ (White Sea worms) or to $25^{\circ} \mathrm{C}$ (North Sea worms). Other specimens were incubated for up to $168 \mathrm{~h}$ at $-1.7^{\circ} \mathrm{C}$, which is the lowest possible sea water temperature above freezing. Critical temperature thresholds had been determined in previous experiments (Sommer et al. 1997). To account for handling artefacts, White Sea worms were also exposed to control temperatures for up to $1 \mathrm{wk}$.

After removal of head and tail, the lugworms were opened by longitudinal dissection and gonads as well as the digestive tract were removed with the help of tissue paper. The body wall musculature was blotted 
dry and freeze clamped in liquid nitrogen by means of a precooled Wollenberger clamp (Wollenberger et al. 1960). Samples were stored in liquid nitrogen until analysed.

Analysis. For the determination of metabolite concentrations body wall tissue was powdered under liquid nitrogen using a precooled mortar and pestle. Approximately $300 \mathrm{mg}$ of powder was added to an excess $(3 \times)$ volume of $0.6 \mathrm{~mol} \mathrm{l}^{-1}$ perchloric acid (PCA) precooled on ice. An Ultra-Turrax T8 (Janke \& Kunkel, Staufen, Germany) was used to homogenize the tissue. Precipitated protein was removed by centrifugation. The extract was neutralised by the addition of $5 \mathrm{mmol}$ $\mathrm{l}^{-1}$ potassium hydroxide and a 1:6 mixture of solid $\mathrm{K}_{2} \mathrm{CO}_{3} / \mathrm{KHCO}_{3}$. A second centrifugation withdrew precipitated potassium perchlorate (Beis \& Newsholme 1975, modified according to Pette \& Reichmann 1982).

After PCA extraction succinate was measured spectrophotometrically in an enzymatic test according to Beutler (1990). Ammonium concentrations were determined enzymatically (Spectrophotometer Biochrom 4060, Pharmacia LKB, Uppsalla, Sweden) following a procedure modified after Bergmeyer \& Beutler (1990). The reaction mixture consisted of $0.2 \mathrm{mmol} \mathrm{l}^{-1} \mathrm{NADH}$,

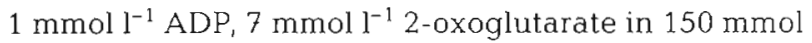
$\mathrm{l}^{-1}$ triethanolamine buffer ( $\mathrm{pH} 8.0$ ). Reaction was initiated by adding glutamate dehydrogenase diluted in glycerol.

A method modified from Fischer (1995) was used to measure the concentrations of the adenylates ATP, ADP and AMP using a high performance liquid chromatograph (Beckman Instruments GmbH, Munich, Germany). Separation was carried out on a Spherisorb $\mathrm{C} 18$ column (Latek, Eppelheim) at $20^{\circ} \mathrm{C}$ and a flow rate of $0.8 \mathrm{ml} \mathrm{min}{ }^{-1}$. The mobile phase consisted of $2 \mathrm{mmol}$ $\mathrm{l}^{-1} 11$-aminoun-decanoic acid in $25 \mathrm{mmol} \mathrm{l}^{-1}$ phosphate buffer with $8 \%(\mathrm{v} / \mathrm{v})$ methanol $(\mathrm{pH}=6)$. Peaks were monitored at $210 \mathrm{~nm}$, using a Diode Array Detector Module 168 (System Gold, Beckman Instruments GmbH, Munich, Germany).

A method modified from Hardewig et al. (1991) was used to measure the concentrations of the fatty acids propionate and acetate in PCA extracts, diluted with deionized water, using a Dionex BIO LC ion chromatograph (Dionex, Idstein, Germany). Fatty acids were separated on an ion exclusion column (Dionex ICEAS 1), using $0.125 \mathrm{mmol} \mathrm{l}^{-1}$ actanesulphonic acid as an eluent at a flow rate of $1 \mathrm{ml} \mathrm{min}^{-1}$ and at $40^{\circ} \mathrm{C}$. Peaks were monitored with a conductivity detector. A micro membrane suppressor (Dionex AMMS-ICE) regenerated with $5 \mathrm{mmol}^{-1}$ tetrabutylammonium hydroxide was used to decrease background conductivity. Calibration curves were linear between acetate and propionate concentrations of 10 and $500 \mu \mathrm{mol} \mathrm{l}^{-1}$.
Alanopine and strombine were measured by cation exchange chromatography. Separation was carried out at $45^{\circ} \mathrm{C}$ on an Interaction $\mathrm{ARH}-601$ column for aromatic acids (ICT-ASS-Chem, Bad Homburg, Germany), using $6 \times 10^{-5} \mathrm{~N} \mathrm{H}_{2} \mathrm{SO}_{4}$ as an eluent at a flow rate of $0.5 \mathrm{ml}$ $\mathrm{min}^{-1}$. A conductivity detector was utilised to monitor the peaks. Standard opine solution for calibration was obtained by means of in vitro synthesis following a method modified from Siegmund \& Grieshaber (1983).

The intracellular buffer value $\left(\beta_{N B}\right)$ of body wall tissue under resting conditions was determined at 15 or $7^{\circ} \mathrm{C}$ following the method of Pörtner (1990). Briefly $0.3 \mathrm{~g}$ of ground tissue were suspended in $4 \mathrm{ml}$ ice-cold medium (540 mmol $\left.\mathrm{l}^{-1} \mathrm{KF}, 10 \mathrm{mmol} \mathrm{l}^{-1} \mathrm{NTA}\right)$ in a temperature controlled tonometer (Instrumentation Laboratory, Padorno Dugano, Italy). The homogenate was equilibrated with different mixtures of $\mathrm{CO}_{2}$ in air 10.75 , $3.62,7.60$ Torr $\mathrm{PCO}_{2}$ ) for at least $10 \mathrm{~min}$ before analysis of $\mathrm{pH}$ and $\mathrm{CCO}_{2}$ took place according to Pörtner et al. (1990). Values of free inorganic phosphate were measured enzymatically according to Pörtner (1990).

Calculations of metabolic proton production. The proton balance of anaerobic metabolism $\left(\Delta \mathrm{H}^{+}\right.$met $)$was evaluated from concentration changes $(\Delta \mathrm{C})$ between control values and $4 \mathrm{~h}$ of heat exposure (Pörtner 1987 a,b) assuming that the accumulation of opines and volatile fatty acids is accompanied by an equal amount of protons, while succinate production is coupled with the release of $2 \mathrm{~mol}$ protons per mol. In a simplified approach changes in adenylate levels were treated as to occur without influence on $\mathrm{pH}$ due to the low $\mathrm{pH}$ after $4 \mathrm{~h}$ of heat stress (Pörtner 1987a). Ammonia is expected to buffer an equimolar amount of protons. Concentration changes of the phosphagen phosphotaurocyamine were not analysed. Therefore, mean control levels were adopted from the literature (Pörtner et al. 1979, Schöttler et al. 1983, 1984a, Schiedek \& Schöttler 1990). Proton binding by the phosphate buffer was calculated for the final $\mathrm{pH}_{1}$, assuming maximum depletion of the phosphagen. The fraction of protonized phosphate $(F)$ is calculated using equation (1) for $\mathrm{pKa}\left(21^{\circ} \mathrm{C}\right)=6.802$ and $\mathrm{pKa}\left(25^{\circ} \mathrm{C}\right)=6.790$ :

$$
F=1 /\left(10^{\mathrm{pH}-\mathrm{pKa}}+1\right)
$$

The amounts of non-respiratory protons (evaluated from the changes in acid-base status caused by metabolic processes or ion-exchange, but not by respiratory processes which involve a change in $\mathrm{PCO}_{2}$ ) were calculated according to:

$$
\Delta \mathrm{H}^{+}{ }_{\text {non-resp }}=-\left|\beta_{N B}\right| \times \Delta \mathrm{pH}_{i}-\Delta \mathrm{Bic}\left(\mathrm{mmol} \mathrm{l}^{-1}\right)
$$

(non-resp.: non respiratory; $\beta_{\mathrm{NB}}$ : non-bicarbonate buffer value; Bic: bicarbonate)

However, changes in bicarbonate concentrations were neglected, since no temperature dependent 
changes had been observed in Arenicola marina blood, coelomic fluid or body wall tissue (Toulmond 1977, Klein 1994).

Statistics. Data were checked for outliers beyond the $r(95)$ limits of an $r$-distribution $\left(r_{A}>r(95)\right)$ using Nalimov's test (Noack 1980). Statistical significance of differences was tested at the $p \leq 0.05$ level using analysis of variance (ANOVA) and the post-hoc StudentNewman-Keuls test for independent samples. Data are given as means \pm standard deviation.

\section{RESULTS}

When lugworms from the North Sea were transferred from 12 to $25^{\circ} \mathrm{C}$, i.e. $4^{\circ} \mathrm{C}$ above their high critical temperature $\left(\mathrm{T}_{c}\right.$ ) (Sommer et al. 1997), the concentrations of strombine and alanopine rose in the body wall tissue (Fig. 1a). Strombine reached a significantly higher level after $4 \mathrm{~h}$ at $25^{\circ} \mathrm{C}$, while the concentration of alanopine was significantly elevated after $24 \mathrm{~h}$ only.
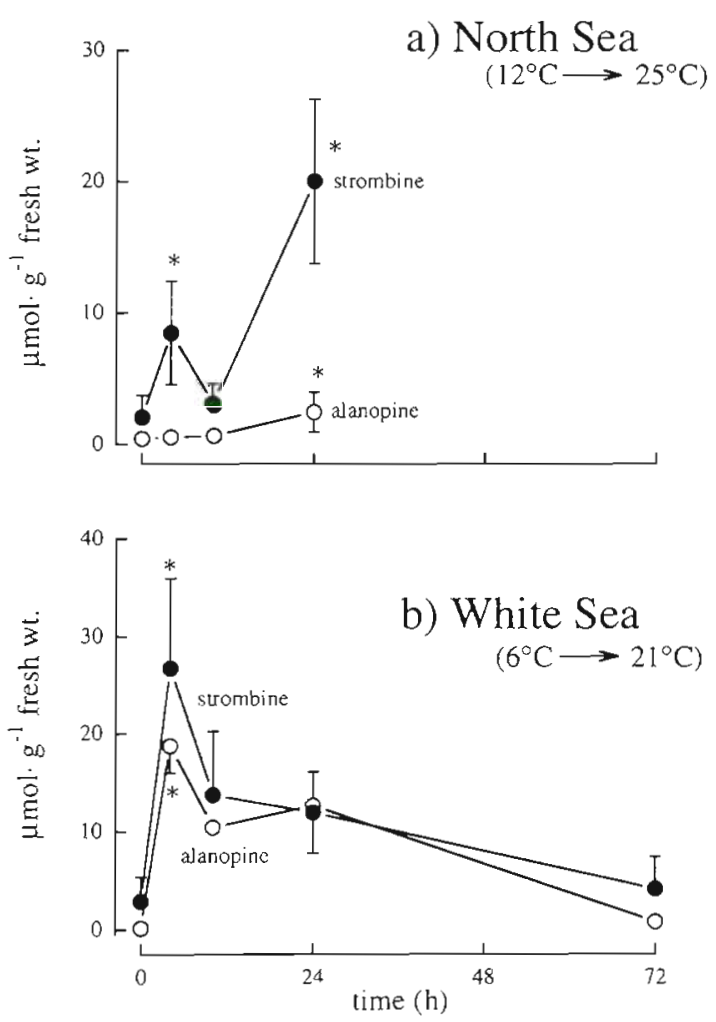

Fig. 1. Concentrations ( $\mu \mathrm{mol} \mathrm{g}^{-1}$ fresh wt) of alanopine and strombine in the body wall tissue of Arenicola marina from (a) the North or (b) the White Sea before and after a temperature rise in the sediment of $4^{\circ} \mathrm{C}$ above their respective critical temperatures. North Sea lugworms were exposed to a temperature elevation from 12 to $25^{\circ} \mathrm{C}$ and White Sea worms from 6 to $21^{\circ} \mathrm{C}$. All North Sea worms died between 24 and $72 \mathrm{~h}$ after the temperature change occurred $\left(n=5 ;\right.$ mean $\pm \mathrm{SD}_{\mathrm{i}}$ *significantly different from the control value at $0 \mathrm{~h}$ )
No adaptive reversal of opine accumulation was seen during $24 \mathrm{~h}$ of exposure to high temperatures. In fact, worms survived for only slightly longer than $1 \mathrm{~d}$. Death of all lugworms occurred within $3 \mathrm{~d}$. In contrast to North Sea lugworms, lugworms from the White Sea not only survived exposure to high temperatures, but also exhibited an adaptive reversal of anaerobic metabolism (Fig. 1b). When temperature was elevated from 6 to $21^{\circ} \mathrm{C}$, i.e. $4^{\circ} \mathrm{C}$ above their high $T_{C}$ the concentrations of both alanopine and strombine increased significantly during the first $4 \mathrm{~h}$, reaching far higher levels than in North Sea specimens. However, the concentrations decreased again after $10 \mathrm{~h}$ and reached control levels within $72 \mathrm{~h}$ (Fig. 1). In White Sea lugworms, succinate reached a high level of $2.53 \pm$ $0.41 \mu \mathrm{mol} \mathrm{g}{ }^{-1}$ fresh wt $(\mathrm{n}=4)$ after $24 \mathrm{~h}$ at $21^{\circ} \mathrm{C}$, compared to $0.07 \pm 0.42 \mu \mathrm{mol} \mathrm{g}{ }^{-1}$ fresh wt $(\mathrm{n}=4)$ in North Sea specimens at $25^{\circ} \mathrm{C}$, and decreased thereafter to a significantly reduced concentration after $3 \mathrm{~d}$ (Fig. 2).

\section{a) North Sea}
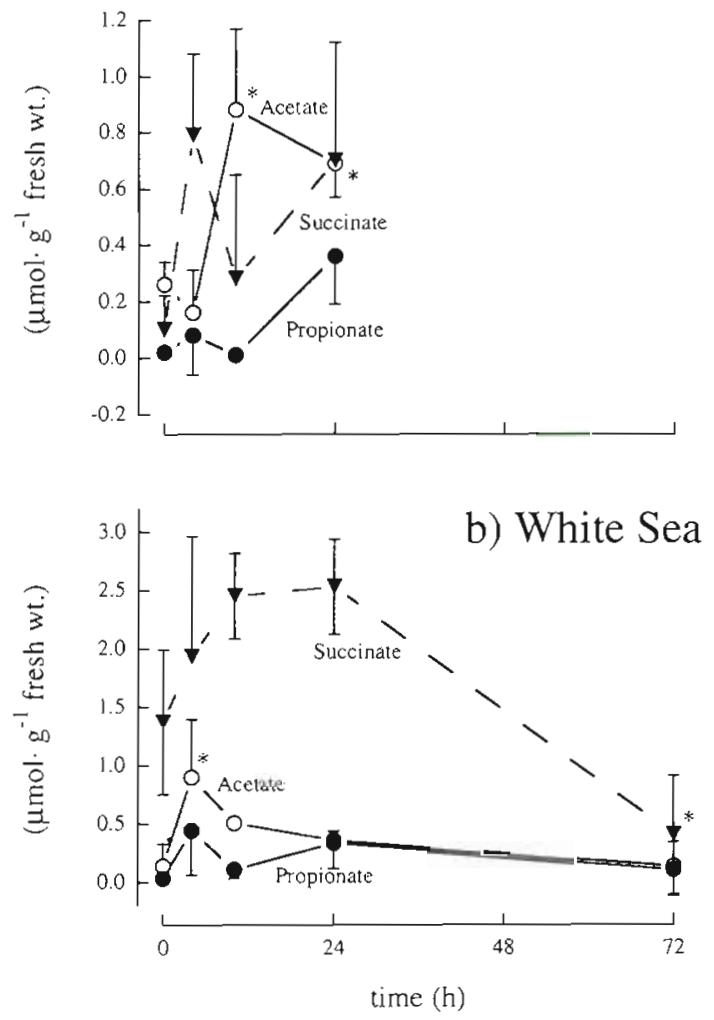

Fig. 2. Concentrations of volatile fatty acids and succinate in the body wall tissue of Arenicola manina from (a) the North or (b) the White Sea after a temperature rise in the sediment $4^{\circ} \mathrm{C}$ above their respective critical temperatures. Differences in succinate concentrations between populations are highly significant $\left(\mathrm{p}=0.0001 ; \mathrm{n}=4-5 ;\right.$ mean $\pm \mathrm{SD}_{i}$ *significantly different from the control value at $0 h_{\text {i }}$ data from North Sea worms and volatile fatty acids in White Sea worms as reported by Sommer et al. 1.997) 
In spite of early death, ATP levels in the body wall tissue of North Sea worms remained unaffected by temperature (Fig. 3a). The concentrations of ADP and AMP increased significantly after the temperature was elevated to $25^{\circ} \mathrm{C}$, leading to significant changes in the [ATP]:[ADP] ratio after $4 \mathrm{~h}$ (Fig. $3 \mathrm{~b}$ ) and a slight, although insignificant, rise in the sum of adenylate levels (Fig. 3c). This picture differs in lugworms from the White Sea (Fig. 4). When temperature was elevated to $21^{\circ} \mathrm{C}$, the ATP store in the body wall tissue was depleted to levels below $0.1 \mu \mathrm{mol} \mathrm{g}^{-1}$ fresh wt during the first $4 \mathrm{~h}$ in the subpolar lugworms and was not replenished before $24 \mathrm{~h}$ (Fig. 4a). Nevertheless, the ability of White Sea lugworms to acclimate to high temperatures was demonstrated when after $72 \mathrm{~h}$ ATP

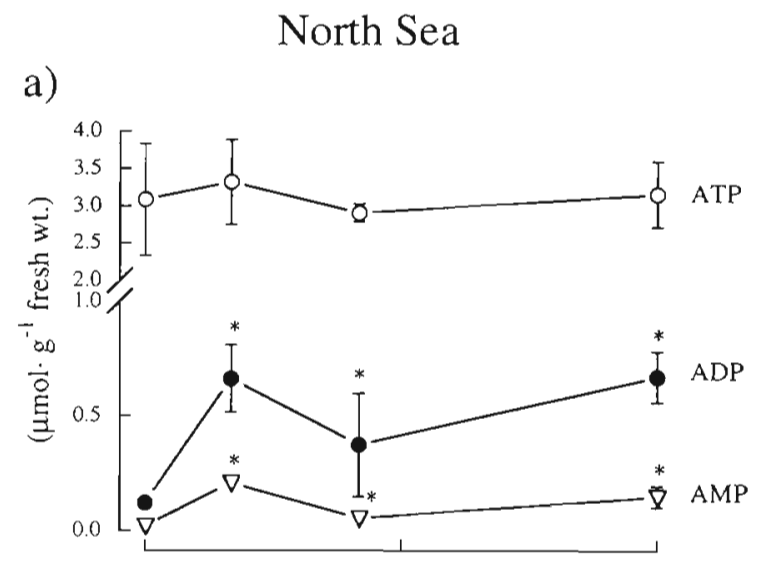

b)
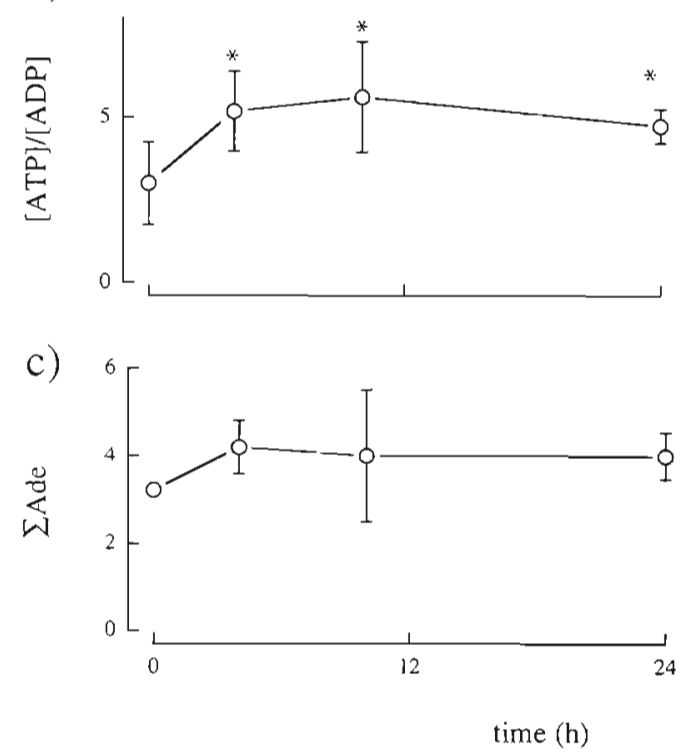

Fig. 3. (a) Adenylate concentrations ( $\mu \mathrm{mol} \mathrm{g}^{-1}$ fresh wt) (b) ratio of [ATP]:[ADP] and (c) summed concentrations ( Ade) of all adenylates (AMP, ADP and ATP) in the body wall tissue of lugworms from the North Sea after an increase in temperature in the sediment from 12 to $25^{\circ} \mathrm{C}$ ( $\mathrm{n}=5$; mean $\pm \mathrm{SD}$; * significantly different from the control value at $0 \mathrm{~h}$ )

\section{White Sea}
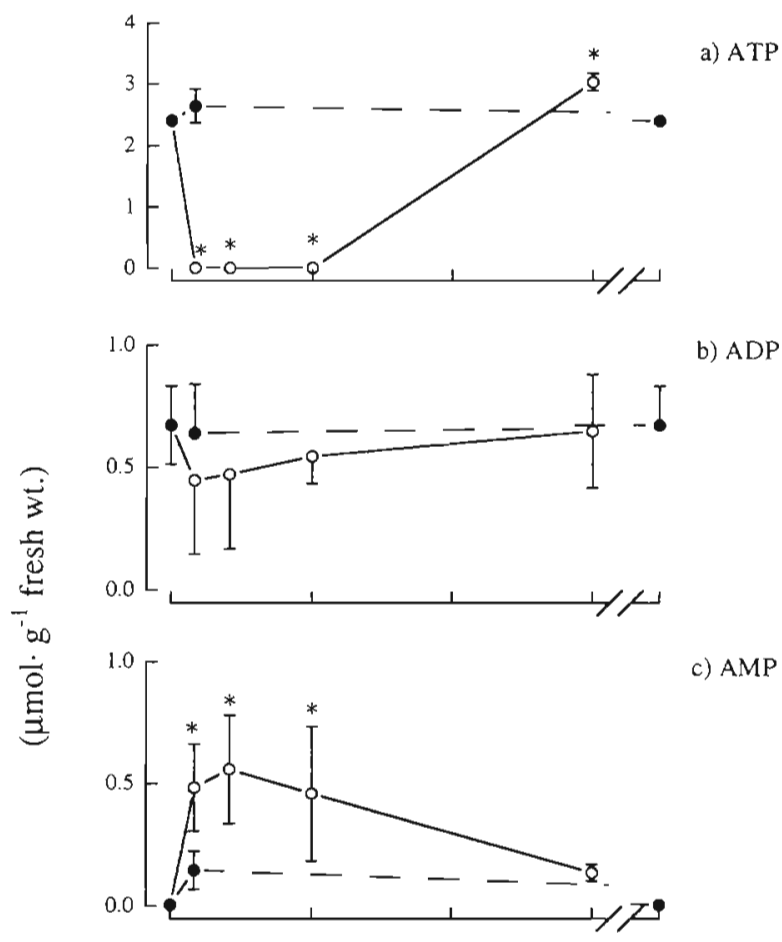

c) $\mathrm{AMP}$

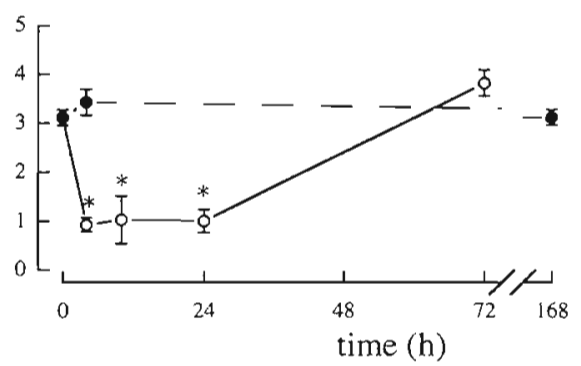

Fig. 4. Concentrations ( $\mu \mathrm{mol} \mathrm{g}^{-1}$ fresh wt) of (a) ATP, (b) ADP (c) AMP and (d) summed concentrations ( $\sum$ Ade) of all adenylates (AMP, ADP and ATP) in the body wall tissue of Arenicola marina (White Sea worms) at constant temperature of $6^{\circ} \mathrm{C}(\bullet)$ and after an increase in temperature in the sediment from 6 to $21^{\circ} \mathrm{C}(0)(\mathrm{n}=5$; mean $\pm \mathrm{SD}$; *significantly different from the control value at $\mathrm{Oh}$ )

reached a concentration that was significantly higher than under control conditions. AMP levels were significantly elevated in the body wall tissue of these worms within $4 \mathrm{~h}$, reaching the highest mean of $0.56 \pm$ $0.22 \mu \mathrm{mol} \mathrm{g}^{-1}$ fresh wt $(\mathrm{n}=5)$ after $10 \mathrm{~h}$ (Fig. $4 \mathrm{c}$ ). An adaptive reversal of AMP accumulation was seen after $72 \mathrm{~h}$, when the mean concentration returned to $0.14 \pm$ $0.03 \mu \mathrm{mol} \mathrm{g}^{-1}$ fresh wt ( $\mathrm{n}=5$ ).

The time course of changes in ammonia concentrations $\left(\left[\mathrm{NH}_{3}\right]+\left[\mathrm{NH}_{4}{ }^{+}\right]\right)$in the body wall tissue is depicted in Fig. 5a. Compared to White Sea worms, lugworms from the North Sea showed small concentration 

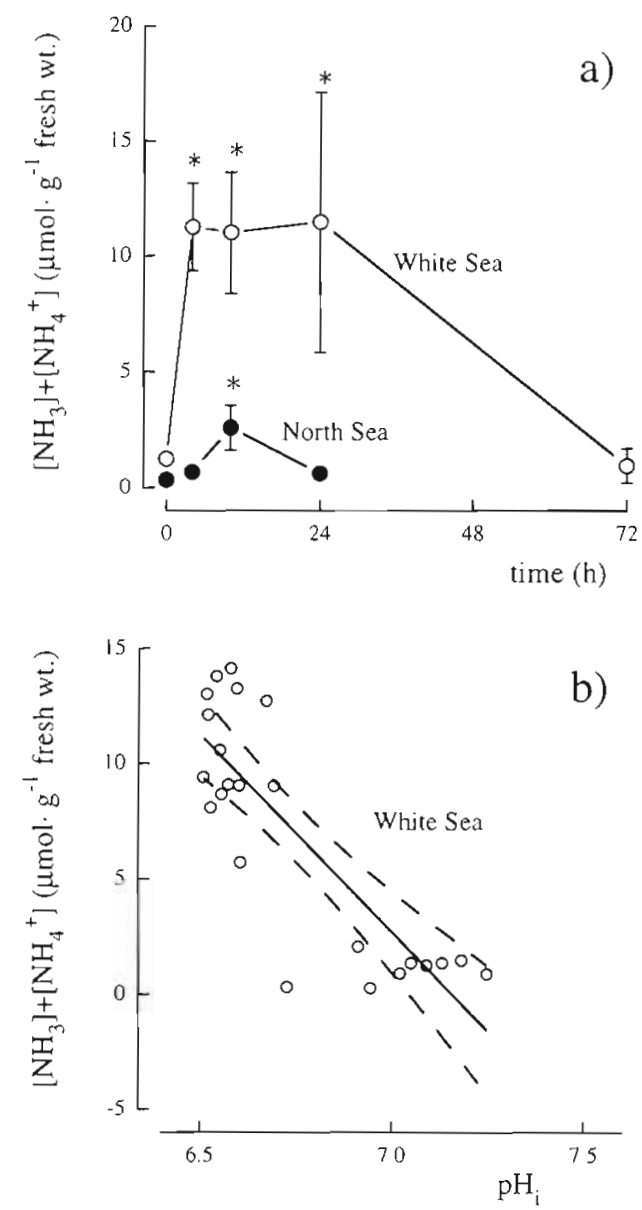

Fig 5. (a) Concentrations ( $\mu \mathrm{mol} \mathrm{\textrm {g } ^ { - 1 }}$ fresh $w \mathrm{t}$ ) of ammonium ions $\left(\left[\mathrm{NH}_{3}\right]+\left[\mathrm{NH}_{4}{ }^{+}\right]\right)$in the body wall tissue of Arenicola marina from the North or White Seas after an increase in temperature in the sediment to a value $4^{\circ} \mathrm{C}$ above their respective critical temperatures $(n=5$; mean $\pm S D$; *significantly different from the control value at $0 \mathrm{~h}$ ). (b) Ammonium concentrations in the body wall tissue of White Sea lugworms as a function of intracellular $\mathrm{pH}$ during exposure to $21^{\circ} \mathrm{C}$. The relationship between both parameters is highly significant

$(\mathrm{p}=0.0001 ; \mathrm{pH}$, data adopted from Sommer et al. 1997)

changes only, but the increase from $0.33 \pm 0.20 \mu \mathrm{mol}$ $\mathrm{g}^{-1}$ fresh wt $(\mathrm{n}=5)$ at $0 \mathrm{~h}$ to $2.59 \pm 0.96 \mu \mathrm{mol} \mathrm{g}^{-1}$ fresh wt ( $\mathrm{n}=5)$ after $10 \mathrm{~h}$ was significant. In White Sea worms, ammonia accumulated to a high level of 11.26 $\pm 1.90 \mu \mathrm{mol} \mathrm{g}{ }^{-1}$ fresh wt $(\mathrm{n}=5)$ already during the first $4 \mathrm{~h}$, after which time the concentration remained constant for $20 \mathrm{~h}$ but returned to control values within $72 \mathrm{~h}$. In lugworms from the White Sea the data reveal a significant correlation between intracellular pH (Fig. 6) and ammonia levels (Fig. 5b).

Heat stress caused a significant drop in intracellular $\mathrm{pH}$ during the first $4 \mathrm{~h}$ of exposure (Fig. 6). Acidification by about $0.2 \mathrm{pH}$-units was observed in North Sea worms, while in specimens from the White $\mathrm{Sea}_{\mathrm{pH}}$ fell by $0.6 \mathrm{pH}$-units. These differences can be partly

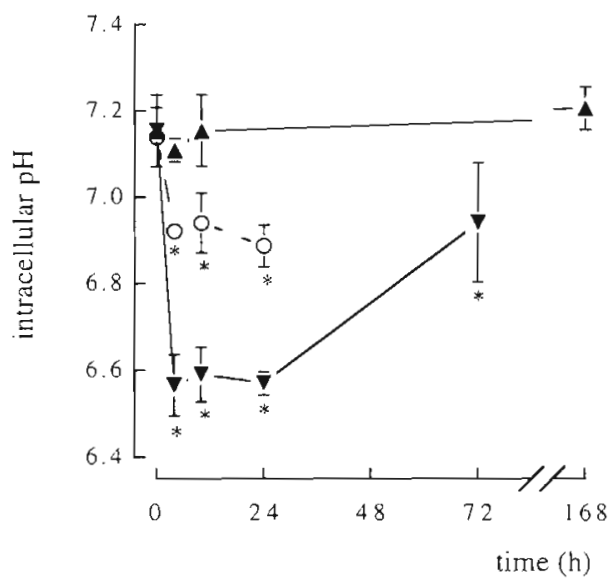

Fig. 6. Intracellular $\mathrm{pH}$ in the body wall tissue of Arenicola marina from the North or White Seas ( $\mathrm{n}=5$; mean $\pm \mathrm{SD}_{i}$ (A) White Sea control lugworms $\left(6^{\circ} \mathrm{C}\right) ;(\nabla)$ White Sea warmed lugworms $\left(6 \text { to } 21^{\circ} \mathrm{C}\right)_{i}(0)$ North Sea warmed lugworms (12 to $25^{\circ} \mathrm{C}$; *significantly different from the control value at $0 \mathrm{~h}$; data as reported by Sommer et al. 1997)

related to the intracellular non-bicarbonate buffer capacity $\left(\beta_{\mathrm{NB}}\right)$ which is significantly higher in lugworms from the North Sea than in White Sea specimens when measured at $15^{\circ} \mathrm{C}$ (Table 1). This comparison of measurements at the same temperature indicates that the buffer capacity decreases with cold adaptation. In addition, the assay temperature influences $\beta_{\mathrm{NB}}$ (van Dijk et al. 1997). In North Sea specimens acclimated to $12^{\circ} \mathrm{C}, \beta_{\mathrm{NB}}$ was slightly and nonsignificantly lower when measured at $7^{\circ} \mathrm{C}(22.79 \pm$ $2.64 \mathrm{mmol} \mathrm{pH}^{-1} \mathrm{~kg}^{-1}$ fresh $\mathrm{wt} \mathrm{n}=5$ ) compared to a value of $26.08 \pm 4.05 \mathrm{mmol} \mathrm{pH}^{-1} \mathrm{~kg}^{-1}$ fresh wt $(\mathrm{n}=4)$ when measured at $15^{\circ} \mathrm{C}$ (Table 1). Metabolic proton production was 7 times higher in the subpolar than in the boreal lugworms (Table 2). This together with the lower buffer capacity in the White Sea lugworms can explain some of the differences in the $\mathrm{pH}$ drop between lugworms of both populations. An excess of metabolic protons in White Sea worms is unexplained by the non-respiratory proton quantities.

Table 1. Intracellular, non-bicarbonate buffer values $\left(\beta_{\mathrm{NB}}\right)$ of resting body wall tissue of Arenicola marina from the North or White Seas. Samples were analysed at 15 or $7^{\circ} \mathrm{C}$, while Iugworms were incubated at their respective control temperature of $12^{\circ} \mathrm{C}$ (North Sea) or $6^{\circ} \mathrm{C}$ (White Sea). Values were significantly different between populations at $15^{\circ} \mathrm{C}(\mathrm{p}<0.05$ mmol $\mathrm{pH}^{-1} \mathrm{~kg}^{-1}$ fresh wt; mean $\pm \mathrm{SD}_{i} \mathrm{n}=4$ )

\begin{tabular}{|ccc|}
$\begin{array}{c}\text { North Sea } \\
-7^{\circ} \mathrm{C}\end{array}$ & $\begin{array}{c}\text { North Sea } \\
-15^{\circ} \mathrm{C}\end{array}$ & $\begin{array}{c}\text { White Sea } \\
-15^{\circ} \mathrm{C}\end{array}$ \\
\hline $22.79 \pm 2.64$ & $26.08 \pm 4.05$ & $20.07 \pm 2.07$ \\
\hline
\end{tabular}


Table 2. Concentrations ( $\mu$ mol $\mathrm{g}^{-1}$ fresh $\mathrm{wt}_{\text {; }}$ mean $\pm \mathrm{SD}$ ) and mean concentration changes $(\Delta \mathrm{C})$ of metabolites in the body wall tissue of Arenicola marina $4 \mathrm{~h}$ after a temperature rise in the sediment from 12 to $25^{\circ} \mathrm{C}$ (North Sea worms) or 6 to $21^{\circ} \mathrm{C}$ (White Sea worms)

\begin{tabular}{|c|c|c|c|c|}
\hline & $\begin{array}{c}\text { Control } \\
\text { Oh }\end{array}$ & $\begin{array}{l}\text { Heat stress } \\
\quad 4 \mathrm{~h}\end{array}$ & $\begin{array}{l}\text { Concentration } \\
\text { changes } \Delta C\end{array}$ & $\begin{array}{l}\text { Mean } \\
\Delta \mathrm{H}^{+} \text {met }\end{array}$ \\
\hline \multicolumn{5}{|c|}{ North Sea worms } \\
\hline Alanopine & $0.43 \pm 0.22$ & $0.53 \pm 0.20$ & +0.10 & +0.10 \\
\hline Strombine & $2.03 \pm 1.70$ & $8.46 \pm 3.93$ & +6.43 & +6.43 \\
\hline Acetate & $0.26 \pm 0.08$ & $0.16 \pm 0.15$ & -0.10 & -0.10 \\
\hline Propionate & $0.02 \pm 0.01$ & $0.08 \pm 0.14$ & +0.06 & +0.06 \\
\hline Succinate & $0.10 \pm 0.12$ & $0.79 \pm 0.29$ & +0.69 & +1.38 \\
\hline ATP & $3.08 \pm 0.75$ & $3.31 \pm 0.57$ & +0.23 & - \\
\hline ADP & $0.12 \pm 0.01$ & $0.66 \pm 0.15$ & +0.54 & - \\
\hline Ammonia & $0.33 \pm 0.20$ & $0.67 \pm 0.26$ & +0.34 & -0.34 \\
\hline \multirow[t]{3}{*}{ P-taurocyamine } & $7.11 \pm 0.63$ & $<0.1$ & -7.01 & -2.98 \\
\hline & & \multicolumn{2}{|c|}{$\begin{array}{l}\Delta \mathrm{H}^{+} \text {met: } \\
\Delta \mathrm{H}_{\mathrm{i}}^{+} \text {non-resp. }\end{array}$} & $\begin{array}{l}+4.55^{d} \\
+6.19\end{array}$ \\
\hline & & \multicolumn{2}{|c|}{ Discrepancy: } & $4(-26 \%)$ \\
\hline \multicolumn{2}{|l|}{ White Sea worms } & & & \\
\hline Alanopine & $0.14 \pm 0.21$ & $18.74 \pm 11.02$ & +18.60 & +18.60 \\
\hline Strombine & $2.89 \pm 2.50$ & $26.72 \pm 9.23$ & +23.83 & +23.83 \\
\hline Acetate & $0.15 \pm 0.12$ & $0.90 \pm 0.50$ & +0.75 & +0.75 \\
\hline Propionate & $0.03 \pm 0.04$ & $0.44 \pm 0.37$ & +0.41 & +0.41 \\
\hline Succinate & $0.09 \pm 0.10$ & $1.93 \pm 1.03$ & +1.84 & +3.68 \\
\hline ATP & $2.41 \pm 0.11$ & $<0.1$ & -2.31 & - \\
\hline ADP & $0.64 \pm 0.20$ & $0.45 \pm 0.30$ & -0.19 & - \\
\hline Ammonia & $1.26 \pm 0.26$ & $11.26 \pm 1.90$ & +10.00 & -10.00 \\
\hline P-taurocyamine & $7.11 \pm 0.63$ & $<0.1$ & -7.01 & -4.42 \\
\hline & & \multicolumn{2}{|c|}{$\begin{array}{l}\Delta \mathrm{H}^{+} \text {mei: } \\
\Delta \mathrm{H}_{1}^{+} \text {non-resp: }\end{array}$} & $\begin{array}{l}+32.85^{\mathrm{a}} \\
+12.07\end{array}$ \\
\hline \multicolumn{5}{|c|}{ Discrepancy: $+20.78(+63 \%)$} \\
\hline \multicolumn{5}{|c|}{$\begin{array}{l}{ }^{a} \text { The proton balance of anaerobic metabolism }\left(\Delta \mathrm{H}^{+} \text {met }\right) \text { was evaluated } \\
\text { from concentration changes }(\Delta \mathrm{C}) \text { according to Pörtner }(1987 \mathrm{a}, \mathrm{b}) \text {. Data } \\
\text { for phosphotaurocyamine consider a maximum effect (see text) during } \\
\text { complete depletion at the } \mathrm{pH}_{\mathrm{i}} \text { value measured after } 4 \mathrm{~h}\end{array}$} \\
\hline
\end{tabular}

vived a temperature drop from 6 or $12^{\circ} \mathrm{C}$ to $-1.7^{\circ} \mathrm{C}$ for more than $1 \mathrm{wk}$, short term cold acclimation in summer lugworms from both areas was incomplete. After an initial rise in the concentrations of succinate, acetate and propionate in the body wall musculature, values returned to control levels after $24 \mathrm{~h}$. However, the concentrations increased again thereafter with succinate reaching high values of $2.42 \pm 3.14 \mu \mathrm{mol} \mathrm{g}^{-1}$ fresh wt in North Sea worms, and $12.01 \pm 5.00 \mu \mathrm{mol} \mathrm{g}^{-1}$ fresh wt in White Sea worms within $7 \mathrm{~d}$.

\section{DISCUSSION}

Populations of the lugworm Arenicola marina are not only exposed to different climates - from polar to subtropic - but also to seasonal and diurnal temperature changes (Wesenberg-Lund 1953, Dörjes 1970, Hartmann-Schröder 1971), Our study was designed to investigate the plasticity of metabolic processes after such temperature changes. End products of anaerobic metabolism were measured as indicators of temperature stress and cold and warm exposure were compared with respect to the time course of acclimation.
For comparison with the adjustment to high temperatures metabolic flexibility was also tested during acute cold exposure. The time course of changes in metabolite levels (Fig. 7) shows that although lugworms from both the White and the North Sea sur-

\section{Adaptational capacity during heat exposure}

Our results indicate that within $3 \mathrm{~d}$ North Sea worms were not able to acclimate to temperatures $4^{\circ} \mathrm{C}$ above the high critical temperature $\left(T_{c}\right)$. In response to a tem-
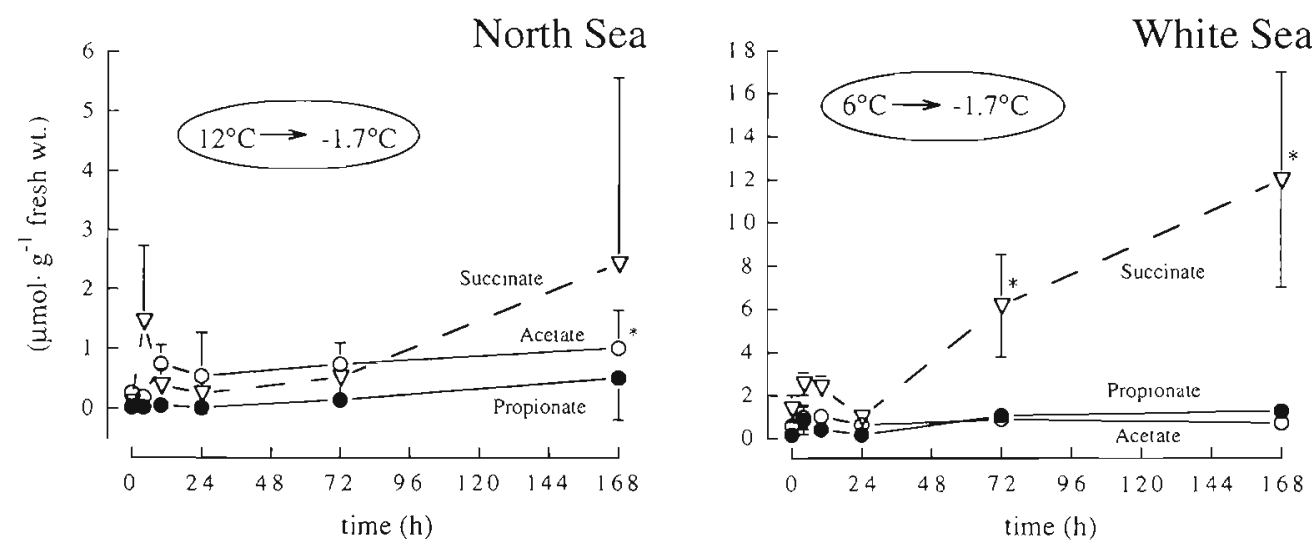

Fig. 7. Concentrations of volatile fatty acids and succinate in the body wall tissue of Arenicola marina after a temperature drop in the sediment from $12^{\circ} \mathrm{C}$ (North Sea worms) or $6^{\circ} \mathrm{C}$ (White Sea worms) to $-1.7^{\circ} \mathrm{C}$. ( $\mathrm{n}=5$; mean \pm SD; ( ) propionate; (o) acetate; $(\nabla)$ succinate; * significantly different from the control value at $0 h_{i}$ data from North Sea worms as reported by Sommer et al. 1997$)$ 
perature change from 12 to $25^{\circ} \mathrm{C}$, alanopine and strombine, volatile fatty acids and succinate accumulated in the body wall tissue before all lugworms died, 1 to $3 \mathrm{~d}$ after the temperature change occurred (Figs. 1a, 2a). It seems that the temperature dependent increase in energy demand, due to an increased metabolic rate with rising temperatures, cannot be met by the ventilatory and circulatory mechanisms of oxygen supply (Sommer et al. 1997, Pörtner et al. 1998, Sommer \& Pörtner unpubl.). Additional anaerobic energy production is required, indicating a transition to a time limited situation.

In contrast to North Sea worms, specimens from the White Sea not only survived for more than $3 \mathrm{~d}$ after temperature was elevated $4^{\circ} \mathrm{C}$ above the high $T_{c}$, but they were actually able to acclimate as indicated by the reversal of an initial transition to anaerobiosis (Figs. 1b, 2b). The development of acid-base disturbances was also reversed within $3 \mathrm{~d}$ after the onset of heat exposure (Fig. 6). The higher adaptational capacity of the subpolar lugworms is especially striking considering their lower weight and higher metabolic rate (Sommer 1998, Sommer \& Pörtner unpubl.). In mussels a correlation was found between metabolic rate (related to higher protein turnover and slower growth) and the sensitivity to high temperatures (Hawkins et al. 1987. Tremblay et al. 1998).

The mechanisms of acclimation may involve an adjustment of mitochondrial density. As a consequence of latitudinal cold adaptation, White Sea worms possess a 2.4 times higher content of mitochondria. In the subpolar worms the number of mitochondria was about 0.12 per $\mu^{2}$ cross-sectional muscle area, whereas North Sea worms possessed only approximately 0.05 per $\mu \mathrm{m}^{2}$ (Sommer \& Pörtner unpubl.). The cost of maintenance of ionic and proton gradients across mitochondrial membranes are expected to be proportional to the number of mitochondria present per unit cell volume (Brand \& Murphy 1987, Pörtner et al. 1998). Mitochondrial density may be reduced during acclimation to higher temperatures, a process which, considering the life span of mitochondria (Alberts et al. 1986), could be accomplished within $5 \mathrm{~d}$. As a consequence, the cost of mitochondrial maintenance is decreased, compensating for the $Q_{10}$ effect on metabolic rate. Owing to the relative drop in standard metabolic rate, the high $T_{c}$ which indicates an imbalance between oxygen consuming and delivering processes, will shift to higher values (Sommer \& Pörtner unpubl.).

As a corollary, the wider range of daily and seasonal temperature fluctuations in the habitat of the White Sea worms (Zenkevitch 1963, Wolff 1983) can be seen as one cause for the higher adaptational capacity of the subpolar worms. In North Sea specimens the limited ability to acclimate to temperature changes may be linked to a limited capacity for adjusting mitochondrial density.

\section{Energy demand and survival strategy}

The level of ATP in the body wall tissue did not change in lugworms from the North Sea during exposure to high temperatures (Fig. 3a). In facultative anaerobes energy turnover is usually depressed during anaerobiosis in comparison to aerobic metabolism (Zebe et al. 1980, Hand \& Hardewig 1996). Thus, ATP concentrations in Arenicola marina decrease only slightly under anoxic conditions at constant temperature, especially since ATP levels are buffered at the expense of phosphotaurocyamine (Schöttler et al. 1983, 1984a,b). Constancy of ATP concentration in spite of heat stress was also found in the water scorpion Ranatra chinensis (Chiba et al. 1991). However, in North Sea lugworms the concentrations of ADP and particularly of AMP increased significantly at high temperatures leading to a downward shift in [ATP]:[ADP] ratios (Fig. 3b). A higher concentration of AMP in the adenylate pool leads to a diminished allosteric inhibition of the phosphofructokinase by ATP (Stryer 1990) and an increase in glycolytic rate. This regulatory feature helps to keep the ATP pool constant during periods of elevated anaerobic energy demand. However, rising concentrations of ADP and AMP at constant ATP levels (Fig. 3a) imply a net synthesis of adenylates at increasing temperatures. Interestingly, Zielinski \& Pörtner (1996) found a net depletion of adenylates at low temperatures in Sipunculus nudus and assumed this phenomenon to be caused by a temperature dependent shift in the reaction equilibrium of AMP deaminase, favouring IMP formation at the expense of AMP. If this process is reversed during warming via enhanced flux through the purine nucleotide cycle, high temperatures would cause net AMP accumulation as seen in the lugworm. This process must subsequently lead to elevated ADP levels since the equilibrium of the adenylate kinase reaction is temperature insensitive (Tewari et al. 1991). The changes observed are consistent with a build-up of adenylates at high temperatures but do not explain why the worms died. Obviously, energy levels were not limiting, at least not in the musculature. These data together with a minor increase in the oxygen consumption rate observed at high temperatures (Sommer \& Pörtner unpubl.) suggest that a large increase in energy expenditure did not occur in North Sea worms whereas this is evident in White Sea specimens. In these worms oxygen consumption 
rose drastically, anaerobic end products were accumulated to a larger extent than in North Sea species and ATP stores were depleted to a level below detection during the first $4 \mathrm{~h}$ at $21^{\circ} \mathrm{C}$. This process was not mirrored by a concomitant increase in ADP levels. AMP concentrations increased only slightly, such that, obviously, a net depletion of total adenylates occurred (Fig. $4 \mathrm{~d}$ ).

A drastic increase in energy demand occurred in White Sea worms at high temperatures. Since the ability to survive heat exposure was improved in White Sea worms, it seems that an energy demanding mechanism exists in this population, which supports survival. The nature of the energy demanding process is unclear, but may involve the synthesis of heat shock proteins, which are induced by a variety of stressors, like heat or cold shock. The energy set free by aerobic (Sommer \& Pörtner unpubl. data) and anaerobic mechanisms could allow, according to a calculation by Atkinson (1977), synthesis of $200 \mu \mathrm{g}$ stress proteins $\mathrm{g}^{-1}$ fresh $w t h^{-1}$, an amount that was also found in bovine skeletal muscle after a temperature increase from 37 to $42^{\circ} \mathrm{C}$ (Gutierrez \& Guerriero 1991). Whatever the mechanisms of survival are, it remains unclear why they are insufficient to support survival at extreme temperatures in North Sea lugworms. Possibly a behavioural avoidance strategy evolved instead in the North Sea population.

In this context it is intriguing that White Sea worms can tolerate a tremendous drop in ATP levels during the period of elevated energy demand at temperatures beyond $\mathrm{T}_{\mathrm{c}}$ 's. Tight regulation of intracellular $\mathrm{pH}$ (see below) and ATP concentration close to control levels may be necessary for the maintenance of locomotory capacity (Hand \& Hardewig 1996). In contrast, a low intracellular $\mathrm{pH}$ at high energy expenditure, for example during the synthesis of heat shock proteins, may be tolerated when locomotory performance is not critical. North Sea worms may manage to avoid heat stress by deepening their burrows which, depending on temperature and season, are up to $70 \mathrm{~cm}$ deep (unpubl. obs.). Thus, North Sea worms may maintain their locomotory capacity in order to escape unfavourable conditions. Since this was not possible in the experimental set-up the increase in temperature proved to be lethal. In contrast, because of a thick layer of clay and rocks most White Sea worms in their natural environment are restricted to a maximum depth of 10 to $15 \mathrm{~cm}$ (unpubl. obs.). This may contribute to why White Sea specimens are adapted to withstand more extreme temperatures than North Sea lugworms. However, this hypothesis has to be reinvestigated in populations of subpolar Arenicola marina which are not restricted to burrows just a few centimeters deep.

\section{Ammonia accumulation}

Heat stress is accompanied by the accumulation of ammonia in the body wall tissue of Arenicola marina. Under the experimental conditions, with a big water volume being available for ammonia excretion, the accumulation in the tissue could either be caused by the trapping of ammonium ions in the animal at low intracellular $\mathrm{pH}$ or by increased ammonia production reflecting a rise in metabolic rate or a shift from carbohydrate to protein catabolism. Additionally, ammonia may be generated by the net depletion of adenylates. In White Sea worms the net depletion of adenylates during the first $4 \mathrm{~h}$ of heat stress amounted to about $2 \mu \mathrm{mol} \mathrm{g}{ }^{-1}$ fresh wt, whereas ammonia concentrations increased by about $10 \mu \mathrm{mol} \mathrm{g}{ }^{-1}$ fresh wt. Since equimolar concentrations of ammonia are released by the hydrolysis of AMP to IMP (Pörtner 1987a) the depletion of adenylates cannot be the only cause of ammonia accumulation. However, the drop in intracellular $\mathrm{pH}$ was more drastic in White Sea than in North Sea worms (Fig. 6), suggesting that high proton concentrations led to the trapping of ammonium ions in the tissue (e.g. Pörtner 1989). Accordingly, a significant correlation was found between intracellular $\mathrm{pH}$ and ammonia concentrations in White Sea worms (Fig. 5b). The increase in metabolic rate during acidosis could lead to an increase in protein catabolism (May et al. 1986) and thereby to ammonia accumulation in the tissue. Actually, Klein (1994) found a reduction of muscle tissue dry weight in Arenicola marina during short term exposure to high temperatures, indicating that muscle proteins were depleted. Altogether, it seems likely that heat stress led to an increase in metabolic rate, supported by enhanced degradation of proteins. Due to the simultaneous drop in intracellular $\mathrm{pH}$, ammonium ions produced were trapped in the tissue. During $3 \mathrm{~d}$ of heat stress the observed recovery in acid-base balance of the subpolar lugworms (Fig. 6) would then also explain why ammonia was able to return to control levels.

\section{Heat stress and acid-base regulation}

Heat stress caused a significant drop in $\mathrm{pH}_{3}$ during the first $4 \mathrm{~h}$ of exposure (Fig. 6). Acidification in White Sea worms even exceeded by far the decrease in $\mathrm{pH}_{\mathrm{i}}$ expected according to the $\alpha$-stat hypothesis by Reeves (1972). The degree of acidification reflects the effects of metabolic and respiratory proton production on cellular buffers. The $\beta_{\mathrm{NB}}$-value in the body wall of North Sea worms was $23 \%$ higher than in White Sea worms (Table 1), possibly reflecting the priority of $\mathrm{pH}$ maintenance in North Sea specimens (see above). In addition, the lower buffer value in White Sea worms may partly 
be related to the higher mitochondrial density (Sommer \& Pörtner unpubl.), since the non-bicarbonate buffer value in the mitochondrial matrix is far lower than in the cytosol (Pörtner \& Sartoris 1999). However, the difference in $\beta_{\mathrm{NB}}$-values cannot fully explain the larger $\mathrm{pH}$ drop in White Sea worms. Contribution of bicarbonate to the buffering process is expected to be low.

Calculations of metabolic proton production from the accumulation of metabolites during heat stress according to Pörtner (1987a) revealed that 7 times more protons were generated in White Sea than in North Sea worms (Table 2). In both populations a discrepancy was observed between the accumulation of protons derived from metabolic pathways $\left(\Delta \mathrm{H}^{+}{ }_{\text {met. }}\right)$ and the non-respiratory changes seen in acid-base status (changes caused by either ion exchange or metabolism, $\Delta \mathrm{H}^{+}$non-resp.i Table 2). This can only partly be explained by the incomplete survey of acid-base relevant metabolite changes. Even when this is taken into account, in White Sea worms metabolic protons are still far in excess of non-respiratory proton quantities. This strongly suggests that in the subpolar worms net proton release occurred from muscle tissues into the coelomic fluid or ambient water (Pörtner 1987b). In contrast, the discrepancy between non-respiratory and metabolic proton quantities is far less in North Sea worms, where non-respiratory protons even exceeded the maximum metabolic proton production calculated assuming maximum phosphagen depletion. This either indicates that the use of phosphagen stores was overestimated or argues for a downregulation of intracellular pH during anaerobiosis (Pörtner 1993). As a corollary, the high metabolic proton production together with the lower buffer values can explain the stronger acidification seen in White Sea compared to North Sea lugworms and reflects the huge difference in anaerobic metabolic rate between the 2 populations. It also stresses the different requirements for tight $\mathrm{pH}$ regulation in both populations (see above).

\section{Surviving cold stress}

Cold stress causes phenomena similar to heat exposure, as seen in an onset of anaerobic metabolism and a decrease in intracellular $\mathrm{pH}$ in cold exposed Arenicola marina as well as in the peanut worm Sipunculus nudus (Fig. 7; Zielinski \& Pörtner 1996, Sommer et al. 1997). In S. nudus a drop in coelomic $\mathrm{Po}_{2}$ and a concomitant onset of anaerobic metabolism was correlated with reduced ventilation at low temperatures (Zielinski \& Pörtner 1996). Summer lugworms from both Arenicola populations were able to tolerate only short term cold stress below the low $T_{c}$ (Fig. 7). As discussed above, latitudinal cold adaptation in Arenicola marina is reflected by the proliferation of mitochondria in muscle tissue as well as by an increase in the aerobic capacity of individual mitochondria (Sommer \& Pörtner unpubl.). This increase in aerobic capacity at low temperatures caused a suppression of anaerobic metabolism and a shift of the low $T_{c}$ to values close to $0^{\circ} \mathrm{C}$ (Sommer et al. 1997). The failure of both summer populations to acclimate to temperatures close to freezing (Fig. 7) may be linked to a limited capacity to adjust mitochondrial density or the aerobic capacity of each individual mitochondrion. This failure is interesting, since lugworms from the White Sea are quite able to acclimatise to subzero temperatures in winter (Kolyakina 1980). Longer periods with slowly decreasing temperatures seem to be required to acclimate to cold conditions. Probably mitochondrial synthesis at low temperatures is much more time consuming than mitochondrial depletion in the heat. In general, cold acclimation is slower than acclimation to high temperatures (Hochachka \& Somero 1984). Costs of mitochondrial synthesis or of enzyme production as well as limitations in available space for more enzymes or mitochondria may be constraints limiting the degree and velocity of cold acclimation. The advantage of prolonged acclimation would be that it allows the costs of mitochondrial or enzyme synthesis to be spread over longer periods.

\section{CONCLUSIONS}

Lugworms from the North and White Seas possess different capacities to cope with heat stress. In contrast to North Sea specimens, lugworms from the White Sea not only survived long term exposure to temperatures above critical, but even exhibited an adaptive reversal of anaerobic metabolism after $3 \mathrm{~d}$. The depletion of ATP stores to very low levels as well as the high rates of anaerobic metabolism observed during the first $24 \mathrm{~h}$ of heat stress lead to the conclusion that an energy consuming process, like the synthesis of heat shock proteins, may be involved in ensuring survival. It is hypothesized that, additionally, mitochondrial density is reduced in the subpolar lugworms during acclimation to high temperatures. This process would reduce the costs of mitochondrial maintenance, compensate for the $Q_{10}$ effect on metabolic rate and would allow the costs of potential heat shock protein synthesis to be paid. A higher rate of metabolic proton production, together with a lower intracellular non-bicarbonate buffer capacity can explain the drastic drop in intracellular $\mathrm{pH}$ observed in Arenicola marina from the White Sea. The larger flexibility in these worms is seen as an adaptation to the larger variability of temperatures at the White Sea and the fact that White Sea lugworms 
are forced to dwell closer to the sediment surface, thereby being even more exposed to more variable surface temperatures than North Sea worms.

The ability to survive cold stress is limited in summer lugworms from both populations. After an initial reversal of anaerobic metabolism, concentrations of volatile fatty acids and succinate continued to increase, indicating insufficient aerobic capacity at temperatures just above freezing. Adjustment to very low temperatures as seen in White Sea worms in winter is therefore likely to require much longer time periods with slowly decreasing temperatures.

Acknowledgements. Parts of the work was carried out at the White Sea Biological Station / Zoological Institute of the Russian Academy of Science in St. Petersburg, Russia. We are grateful for the excellent support of Dr V. V. Fedjakov and Dr A. A. Sukhotin and all the helpful hands at the station. We also thank T. Hirse and $G$. Frank for their technical assistance. Alfred-Wegener-Institute Publication No. 1610.

\section{LITERATURE CITED}

Alberts B, Bray D, Lewis J, Raff M, Roberts K, Watson JD (1986) Molekularbiologie der Zelle. VCH Verlagsgesellschaft, Weinheim

Atkinson DE (1977) Cellular energy metabolism and its regulation. Academic Press, New York, p 70-79

Beis I, Newsholme EA (1975) The contents of adenine nucleotides, phosphagens and some glycolytic intermediates in resting muscles from vertebrates and in invertebrates. Biochem J 152:23-32

Bergmeyer HU, Beutler HO (1990) Ammonia. In: Bergmeyer HU (ed) Methods of enzymatic analysis, Vol VIII. VCH Verlagsgesellschaft, Weinheim, p 454-461

Beutler HO (1990) Succinate. In: Bergmeyer HU (ed) Methods of enzymatic analysis, Vol VII. VCH Verlagsgesellschaft, Weinheim, p 25-33

Brand MD, Murphy MP (1987) Control of electron flux through the respiratory chain in mitochondria and cells. Biol Bull 62:141-193

Chiba A, Hamaguchi M, Tokuno T, Asai T, Okuda H, Chichibu S (1991) Changes in high-energy phosphate metabolism in the water scorpion. Ranatra chinensis, under cold water-warm water stress. Comp Biochem Phyisiol 100: $399-405$

Dörjes J (1970) Ökofaktoren. In: Reineck HE (ed) Das Watt. Dr. Kramer Verlag, Frankfurt/Main, p 17

Easterling DR, Horton B, Jones PD, Peterson TC, Karl TR, Parker DE, Salinger MJ, Razuvayev $V$, Plummer $N$, Jamason P, Folland CK (1997) Maximum and minimum temperature trends for the globe. Science 277:364-367

Fischer JH (1995) Specific detection of nucleotides, creatine phosphate, and their derivatives from tissue in a simple, isocratic, recycling, low volume system. LC GC Int 8:254

Govberg LI (1973) Holocene molluscs of the White Sea. Shirshov Institute of Oceanology, USSR Academy of Sience, p 547-551

Gregory JM, Oerlemans J (1998) Stimulated future sea-level rises due to glacier melt based on regionally and seasonally resolved temperature changes. Nature 391:474-476

Grieshaber MK, Hausschild K, Sommer A, Völkel S (1993)
Anaerobiosis and sulphobiosis in the lugworm, Arenicola marina L. In: Eleftharious A, Ansell AD, Smith CJ (eds) Biology and ecology of shallow coastal waters. Olsen \& Olsen, Fredensborg, p 131-137

Gutierrez JA, Guerriero V Jr (1991) Quantitation of Hsp70 in tissue using a competitive enzyme-linked immunosorbent assay. J Immunol Methods 143:81-88

Hand SC, Hardewig I (1996) Downregulation of cellular metabolism during environ-mental stress: mechanisms and implications. Annu Rev Physiol 58:539-563

Hardewig I, Addink ADF, Grieshaber MK, Pörtner HO, van den Thillart G (1991) Metabolic rates at different oxygen levels determined by direct and indirect calorimetry in the oxyconformer Sipunculus nudus. J Exp Biol 157:143-160

Hartmann-Schröder G (1971) Annelida, Borstenwürmer, Polychaeta. In: Dahl M, Peus F (eds) Die Tierwelt Deutschlands und der angrenzenden Meeresteile. VEB Gustav Fischer Verlag, Jena, p 445-448

Hawkins AJS, Wilson IA, Bayne BL (1987) Thermal responses reflect protein turnover in Mytilus edulis L. Funct Ecol 1: 339-351

Hochachka PW, Somero GN (1984) Biochemical adaptation. Princeton University Press, Princeton, New Jersey

Hummel H, Sommer A, Bogaards RH, Poertner HO (1997) Variation in genetic traits of the lugworm Arenicola marina: temperature related expression of mitochondrial allozymes? Mar Ecol Prog Ser 159:189-195

Kaufmann RK, Stern DI (1997) Evidence for human influence on climate from hemispheric temperature relationships. Nature 388:39-44

Kerr RA (1998) The hottest year, by a hair. Science 279 : $315-316$

Klein B (1994) Zur Temperaturabhängigkeit physiologischer Prozesse bei Arenicola marina (L.): Energiestoffwechsel und Säure-Basen-Haushalt. Diplomarbeit, Düsseldorf

Kolyakina NM (1980) The seasonal and age characteristics in the distribution of lugworm Arenicola marina (Polychaeta) in the Kislaya inlet of the Kandalaksha Bay. Biology of the White Sea 5:77-92

Krüger F (1964) Versuch über die Abhängigkeit der Atmung von Arenicola marina (Annelides Polychaeta) von Größe und Temperatur. Helgol Wiss Meeresunters 10:38-63

May RC, Kelly RA, Mitch WE (1986) Metabolic acidosis stimulates protein degradation in rat muscle by a glucocorticoid-dependent mechanism. J Clin Invest 77:614-621

Nesis KN (1983) A hypothesis on the origin of Western and Eastern Arctic distribution areas of marine bottom animals. Biologya Morya 5:3-13

Noack S (1980) Statistische Auswertung von Meß- und Versuchsdaten mit Taschenrechner und Tischcomputer Walter de Gruyter, Berlin

Pette D, Reichmann H (1982) A method for quantitative extraction of enzymes and metabolites from tissue samples in the milligram range. J Histochem Cytochem 30:401-402

Pörtner HO (1987a) Contribution of anaerobic metabolism to $\mathrm{pH}$-regulation in animal tissues: theory. J Exp Biol 131: $69-87$

Pörtner HO (1987b) Anaerobic metabolism and changes in acid-base status: quantitative interrelationships and $\mathrm{pH}$ regulation in the marine worm Sipunculus nudus. J Exp Biol 131:89-105

Portner HO (1989) The importance of metabolism in acid-base regulation and acid-base methodology. Can J Zool 67 : 3005-3017

Pörtner HO (1990) Determination of intracellular buffer values after metabolic inhibition by fluoride and nitrilotriacetic acid. Resp Physiol 81:275-288 
Pörtner HO (1993) Multicompartmental analyses of acid-base and metabolic homeostasis during anaerobiosis: invertebrate and lower vertebrate examples. In: Hochachka PW, Lutz PL, Sick T, Rosenthal M, van den Thillart G (eds) Surviving hypoxia: mechanisms of control and adaptation. CRC Press Inc., Boca Raton, Fl, p 139-156

Portner HO, Sartoris FJ (1999) Invasive studies of intracellular acid-base parameters: environmental and functional aspects. In: Taylor EW, Egginton S, Raven JA (eds) Regulation of tissue $\mathrm{pH}$ in plants and animals: a reappraisal of current techniques. Cambridge University Press, in press

Pörtner HO, Surhold B, Grieshaber M (1979) Recovery from anaerobiosis of the lugworm, Arenicola marina L. changes of metabolite concentrations in the body-wall musculature. J Comp Physiol 133:227-231

Pörtner HO, Boutilier RG, Tang Y, Toews DP (1990) Determination of intracellular $\mathrm{pH}$ and $\mathrm{PCO}_{2}$ after metabolic inhibition by fluoride and nitrilotriacetic acid. Resp Physiol 81 $255-274$

Pörtner HO, Hardewig I, Sartoris FJ, van Dijk PLM (1998) Acid-base balance, ion regulation and energetics in the cold. In: Pörtner HO, Playle RC (eds) Cold ocean physiology. Cambridge University Press, p 88-120

Reeves RB (1972) An imidazole alphastat hypothesis for vertebrate acid-base regulation: tissue carbon dioxide content and body temperature in bullfrogs. Resp Physiol 14:219-236

Schiedek D, Schöttler U (1990) The energy production of juvenile Arenicola marina (Polychaeta) under anoxia and hypoxic conditions. Helgol Wiss Meeresunters 44:135-145

Schmidt R, Schiedek D, Schöttler U (1992) Der Einfluß der Temperatur auf den anaeroben Energiestoffwechsel von Arenicola marina L. (Polychaeta). Verh Dtsch Zool Ges 92:167

Schöttler U, Wienhausen G, Zebe E (1983) The mode of energy production in the lugworm Arenicold marina at different oxygen concentrations. J Comp Physiol 149 . $547-555$

Schöttler U, Surholt B, Zebe E (1984a) Anaerobic metabolism in Arenicola marina and Nereis diversicolor during low tide. Mar Biol 81:69-73

Schöttler U. Wienhausen G, Westermann J (1984b) Anaerobic metabolism in the lugworm Arenicola marina L.: the transition from aerobic to anaerobic metabolism. Comp Biochem Physiol 79B:93-103

Seymour MK (1972) Effects of temperature changes on irrigation rate in Arenicola marina (L.). Comp Biochem Physiol 43:553-564

Siegmund B, Grieshaber MK (1983) Determination of mesoalanopine and D-strombine by high pressure liquid chromatography in extracts from marine invertebrates. Hoppe Seyler's Z Physiol Chem 364:807-812

Editorial responsibility: Otto Kinne (Editor), Oldendorf/Luhe, Germany
Sommer A (1998) Mechanismer und Grenzen der Temperaturanpassung beim Pierwurm Arenicola marina (L.). Berichte zur Polarforschung 285, Alfred-Wegener-Institut, Bremerhaven

Sommer A, Klein B, Pörtner HO (1997) Temperature induced anaerobiosis in two populations of the polychaete worm Arenicola marina (L.). J Comp Physiol 167B:25-35

Stryer L (1990) Biochemie. Spectrum der Wissenschaft, Spectrum der Wissenschaft Verlag GmbH, Heidelberg

Tewari YB, Goldberg RN, Advani JV (1991) Thermodynamics of the disproportionation of adenosine 5 -diphosphate to adenosine $5^{\prime}$-triphosphate and adenosine 5 '-mono-phosphate. II. Experimental data. Biophys Chem 40:263-276

Toulmond A (1975) Blood oxygen transport and metabolism of the confined lugworm Arenicola marina. J Exp Biol 63: $647-660$

Toulmond A (1977) Temperature-induced variations of blood acid-base status in the lugworm, Arenicola marina. (L.) I. In vitro study. Resp Physiol 31:139-149

Toulmond A, Tchernigovtzeff $C$ (1984) Ventilation and respiratory gas exchange of the lugworm Arenicola marina (L.) as a function of ambient pO2 (20-700 Torr). Resp Physiol 57:349-363

Tremblay R, Myrand B, Guderley H (1998) Thermal sensitivity of organismal and mitochondrial oxygen consumption in relation to sesceptibiliy of blue mussels, Mytilus edulis (L.), to summer mortality. J Shellfish Res 17(1):141-152

van Dijk PLM, Hardewig I, Pörtner HO (1997) Temperaturedependent shift of $\mathrm{pH}_{\mathrm{i}}$ in fish white muscle: contributions of passive and active processes. Am J Physiol 272:R84-R89

Völkel S, Grieshaber MK (1992) Mechanisms of sulphide tolerance in the peanut worm, Sipunculus nudus (Sipunculidae) and in the lugworm Arenicola marina (Polychaeta). J Comp Physiol 162B:469-477

Wells GP (1964) Temperature, taxonomic technique and the zoogeography of lugworms (Arenicolidae, Polychaeta). Helgol Wiss Meeresunters 10:404-410

Wesenberg-Lund E (1953) The zoology of east Greenland, Vol 122(3), C.A. Reitzel Forlag, Copenhagen

Wolff WJ (ed) (1983) Ecology of the Wadden Sea. Vol 1, Chap. 2: hydrography. A A Balkema, Rotterdam

Wollenberger AO, Ristau O, Schoffa G (1960) Eine einfache Technik der extrem schnellen Abkühlung großer Gewebestücke. Pflügers Archiv-Euro J Physiol 270:399-412

Zebe E, Grieshaber M, Schöttler U (1980) Biotopbedingte und funktionsbedingte Anaerobiose. Biol Unserer Zeit 6: $175-182$

Zenkevitch L (1963) Biology of the Seas of the U.S.S.R. George Allen \& Unwin Ltd, London

Zielinski S, Pörtner HO (1996) Energy metabolism and ATP free-energy change of the intertidal worm Sipunculus nudus below a critical temperature. J Comp Physiol 166B:492-500

Submitted: May 5, 1998; Accepted: December 1, 1998 Proofs received from author(s): April 27, 1999 